\title{
Effect of Acute and Chronic Electroconvulsive Shock on 5-Hydroxytrypamine 6 Receptor Immunoreactivity in Rat Hippocampus
}

\author{
Hyun Jung Kim ${ }^{1}$, Seungwoo Kang ${ }^{1}$, Hyun Ju Kim ${ }^{1}$, Sun-Hye Choi ${ }^{1}$, Seungkeun Shin ${ }^{1}$, \\ Hyung Ha Lee ${ }^{1}$, Hyewhon Rhim ${ }^{2 *}$ and Kyung Ho Shin ${ }^{1 *}$ \\ ${ }^{1}$ Department of Pharmacology, Korea University College of Medicine, Seoul 136-705, \\ ${ }^{2}$ Center for Neuroscience, Korea Institute of Science and Technology, Seoul 136-791, Korea
}

\begin{abstract}
Electroconvulsive shock (ECS) induces not only an antidepressant effect but also adverse effects such as amnesia. One potential mechanism underlying both the antidepressant and amnesia effect of ECS may involve the regulation of serotonin (5-hydroxytryptamine) 6 (5-HT6) receptor, but less is known about the effects of acute ECS on the changes in 5-HT6 receptor expression in the hippocampus. In addition, as regulation of 5-HT receptor expression is influenced by the number of ECS treatment and by interval between ECS treatment and sacrifice, it is probable that magnitude and time-dependent changes in 5-HT6 receptor expression could be influenced by repeated ECS exposure. To explore this possibility, we observed and compared the changes of 5-HT6 receptor immunoreactivity (5-HT6 IR) in rat hippocampus at 1,8, 24, or $72 \mathrm{~h}$ after the treatment with either a single ECS (acute ECS) or daily ECS for 10 days (chronic ECS). We found that acute ECS increased 5-HT6 IR in the CA1, CA3, and granule cell layer of hippocampus, reaching peak levels at $8 \mathrm{~h}$ and returning to basal levels $72 \mathrm{~h}$ later. The magnitude and time-dependent changes in 5-HT6 IR observed after acute ECS were not affected by chronic ECS. These results demonstrate that both acute and chronic ECS transiently increase the 5-HT6 IR in rat hippocampus, and suggest that the magnitude and time-dependent changes in 5-HT6 IR in the hippocampus appear not to be influenced by repeated ECS treatment.
\end{abstract}

Key words: electroshock, hippocampus, serotonin 6 receptor

Received March 18, 2014, Revised May 30, 2014,

Accepted June 2,2014

\footnotetext{
* To whom correspondence should be addressed. Kyung Ho Shin

TEL: 82-2-920-6195, FAX: 82-2-927-0824

e-mail:kyungho@korea.ac.kr

Hyewhon Rhim

TEL: 82-2-958-5923, FAX: 82-2-958-5909

e-mail:hrhim@kist.re.kr
}

\section{INTRODUCTION}

Electroconvulsive shock (ECS) is one of the most effective treatments for depressed patients who have not responed to antidepressant treatment [1]. Although neurochemical effects that underlie therapeutic effect of ECS are not clear, it is generally thought that ECS-induced regulation of serotonin (5-hydroxytryptamine, 5-HT) neurotransmission and its receptors may be involved in therapeutic effect of ECS. Among the 5-HT receptors, ECS-induced regulation of 5-HT1A and 5-HT2A receptors in brain has been the subject of much investigation
Copyright $\odot$ Experimental Neurobiology 2014. www.enjournal.org
This is an Open Access article distributed under the terms of the Creative Commons Attribution Non-Commercial License (http://creativecommons.org/licenses/by-nc/3.0) which permits unrestricted non-commercial use, distribution, and reproduction in any medium, provided the original work is properly cited. 
because chronic antidepressant treatment often activates 5-HT1A receptor function in the dorsal hippocampus [2], but blocks the 5-HT2A receptor function in the cortex [3]. In addition to beneficial effects such as antidepressant effect, ECS also induces some adverse effects including amnesia. Patients treated with ECS often report deficits in memory retention of newly acquired information (anterograde amnesia) or memory recalling in events before the ECS (retrograde amnesia) $[4,5]$.

One potential mechanism underlying ECS-induced antidepressant effect and amnesia may be related to the regulation of 5-HT6 receptor. The involvement of the 5-HT6 receptor in the antidepressant and amnesia effects of ECS is supported by several lines of evidence. The 5-HT6 receptor is diffusely distributed within the hippocampus [6-8], a brain area engaged in the antidepressant effect $[9,10]$ as well as in learning and memory [11]. A 5-HT6 receptor antagonist demonstrates antidepressant-like effect in the forced swimming test (FST) and tail suspension test (TST), both of which have been used for screening antidepressant efficacy [12, 13]. Moreover, 5-HT6 receptor antagonist not only enhances the retention of spatial memory, but also attenuates scopolamine-induced amnesia [14-16]. Therefore it is probable that alteration of 5-HT6 receptor in the hippocampus may be involved in ECS-induced antidepressant effect and amnesia.

However, little work has been done whether ECS dynamically regulates 5-HT6 receptor expression in the hippocampus. In addition, a single ECS is often ineffective to treat depression, and repeated ECS treatments are needed to obtain clinical antidepressant effect [17]. Moreover, changes in 5-HT receptor expression after ECS are affected by the number of treatment and by interval between the ECS treatment and sacrifice. For example, a single and repeated ECS have varying effects on magnitude and direction of changes in 5-HT1A and 5-HT2A receptors expression in the hippocampus [18]. Accordingly, it is possible that repeated ECS may differentially regulate the magnitude and time-dependent changes in 5-HT6 receptor expression in the hippocampus compared to acute ECS. To explore these possibilities, in the present study, we observed and compared the changes of 5-HT6 receptor immunoreactivity (5-HT6 IR) in rat hippocampus following a single ECS treatment (acute ECS) with those following daily ECS treatments for 10 days (chronic ECS).

\section{MATERIALS AND METHODS}

\section{Animals}

Adult male Sprague Dawley rats (250-300 g, Orient, Gapyeong, Korea) were obtained 1 week prior to the experiment and were housed three per cage under a $12 \mathrm{~h}$ light-dark cycle (lights on at
06:00 h). Food and water were available ad libitum. All procedures used in this study were consistent with the National Institutes of Health Guidelines for the Care and Use of Laboratory Animals.

\section{ECS}

Adult male Sprague Dawley rats received a single ECS via earclip electrodes (acute ECS) or daily ECS for 10 days (chronic ECS). ECS was administered via ear clip electrodes with a pulse generator $(60 \mathrm{~mA}, 100 \mathrm{pulses} / \mathrm{sec}$, shock duration $0.5 \mathrm{sec})$. Control animals were handled identically to ECS-treated animals but without electrical stimulation according to previous reports [19, 20], in which animals exposed only sham treatment were used as control group for chronic ECS treatment. Rats were sacrificed $1 \mathrm{~h}$, $8 \mathrm{~h}, 24 \mathrm{~h}$, or $72 \mathrm{~h}$ after the last ECS application.

\section{Tissue preparation}

Following anesthesia, rats were perfused intracardially with 100 $\mathrm{ml}$ of $0.9 \%$ saline, followed by $400 \mathrm{ml}$ of $4 \%$ paraformaldehyde in $0.1 \mathrm{M}$ sodium phosphate buffer (PPB, pH 7.2). Brains were fixed in situ for $1 \mathrm{~h}$, removed, post-fixed in PPB for $2 \mathrm{~h}$, and then placed in $20 \%$ sucrose/PPB overnight at $4^{\circ} \mathrm{C}$ for cryoprotection. Serial coronal sections $(30 \mu \mathrm{m})$ were made through the entire brain using a Microm HM450 sliding microtome and were stored in a cryoprotectant solution (30\% RNase free sucrose, 30\% ethylene glycol, and 1\% polyvinyl pyrrolidone 40 in $100 \mathrm{mM} \mathrm{PPB,pH} \mathrm{7.4)}$ at $-20^{\circ} \mathrm{C}$.

\section{Immunohistochemistry}

Brain sections were incubated in $1 \% \mathrm{H}_{2} \mathrm{O}_{2}$ in $0.01 \mathrm{M}$ phosphatebuffered saline (PBS, pH 7.4) for 10 min to block endogenous peroxidase activity, and then in PBS containing 0.3\% Triton X-100, $4 \%$ normal goat serum, and $2.5 \%$ bovine serum albumin for 1 $\mathrm{h}$ at room temperature. After that, the sections were incubated for $24 \mathrm{~h}$ at $4^{\circ} \mathrm{C}$ with an anti-5-HT6 receptor polyclonal rabbit antibody (1:1,000 dilution) as described previously [21]. The sections were then incubated with biotinylated goat anti-rabbit IgG (1:500; Vector Laboratories, Burlingame, CA, USA) for $24 \mathrm{~h}$ at $4^{\circ} \mathrm{C}$. After being rinsed three times for $10 \mathrm{~min}$ each time with $0.01 \mathrm{M}$ PBS, the sections were incubated in an avidin-biotinperoxidase complex (1:500; Vector Laboratories) for $3 \mathrm{~h}$ at room temperature. After rinsing, sections were incubated for $10 \mathrm{~min}$ in $0.05 \%(\mathrm{w} / \mathrm{v})$ diaminobenzidine solution containing $0.3 \% \mathrm{H}_{2} \mathrm{O}_{2}$. The sections were then rinsed with PBS, mounted on glass slides, dried overnight, dehydrated, and cover-slipped under Permount (Fisher Scientific, Pittsburgh, PA, USA). 


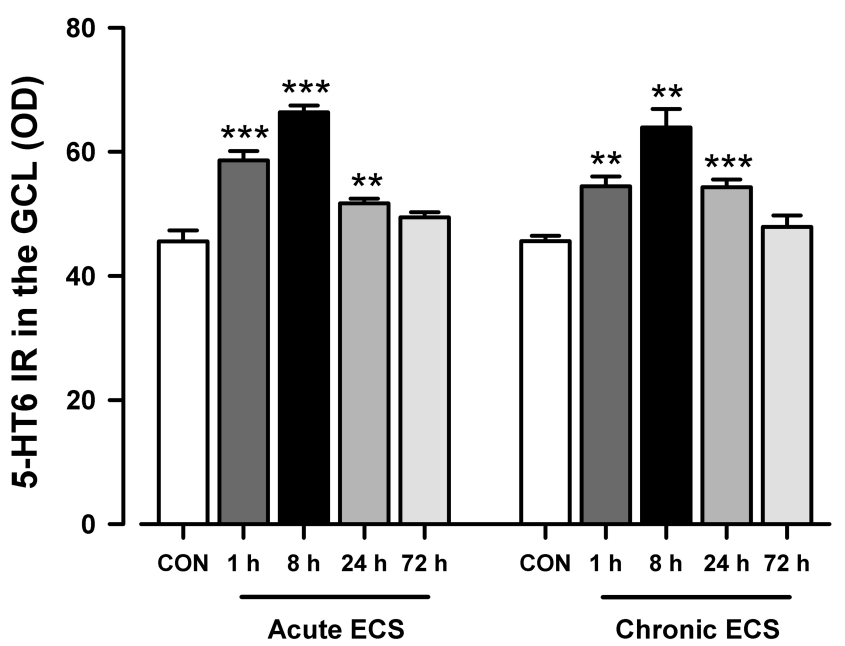

Fig. 1. Time-dependent changes in 5-HT6 receptor immunoreactivity (5-HT6 IR) levels in the granule cell layer (GCL) of hippocampus after acute and chronic ECS. Rats were administrated acute and chronic ECS and sacrificed 1, 8, 24, and $72 \mathrm{~h}$ later. Abbreviations used: $0 \mathrm{~h}$, sham control; 1 h, sacrificed $1 \mathrm{~h}$ following ECS; 8 h, sacrificed $8 \mathrm{~h}$ following ECS; $24 \mathrm{~h}$, sacrificed $24 \mathrm{~h}$ following ECS; $72 \mathrm{~h}$, sacrificed $72 \mathrm{~h}$ following ECS. The results are expressed as the optical density (OD) and represent means \pm standard error of the mean (SEM) of data from 9 rats in each group. ${ }^{*} \mathrm{p}<0.05$ and ${ }^{* * *} \mathrm{p}<0.001$ vs. $0 \mathrm{~h}$ (by one-way ANOVA followed by post hoc Tukey's honestly significant difference test or post hoc Dunnett's T3 test).

\section{Data analysis and statistics}

Images of the 5-HT6 IR were captured using a ProGress C14 CAMERA (Jenoptik, Jena, Germany) mounted on an Olympus BX-50 microscope. Sections of hippocampus (-3.60 to $-3.80 \mathrm{~mm}$ from Bregma) were selected and analyzed [22]. To quantify the level of 5-HT6 IR, the regions of interest on sections were outlined, and then 5-HT6 IR optical densities were measured using Scion Image alpha 4.0 software (Scion Corporation, Frederick, MD, USA), and background staining levels in the corpus callosum were subtracted from these measurements. To compare 5-HT6 IR levels, statistical analysis was performed using one-way analysis of variance (ANOVA) followed by post hoc analysis using Tukey's honestly significant difference test. If homogeneity of the variances was not satisfied, one-way ANOVA with Welch's robust test of equality of means with post hoc Dunnett's T3 test were used to analyze significant difference among groups $[23,24]$. Significance was accepted for $p$ values $<0.05$.

\section{RESULTS}

Acute ECS significantly increased 5-HT6 IR in the CA1, CA3, and granule cell layer (GCL) of the hippocampus in a timedependent manner. One way ANOVA analysis shows that there was a significant differences in the CA1 $(\mathrm{F} 4,40=53.2, \mathrm{p}<0.001)$, CA3 (F4,19.0=12.8, p<0.001), and GCL $(\mathrm{F} 4,40=43.9, \mathrm{p}<0.001)$. Specifically, 5-HT6 IR levels were generally increased from $1 \mathrm{~h}$ in the CA1 $(+10.1 \%, \mathrm{p}<0.01), \mathrm{CA} 3(+12.7 \%, \mathrm{p}=0.553)$, and GCL $(+31.1 \%, \mathrm{p}<0.01)$ of the hippocampus, and reached peak levels by 8 h post-ECS in CA1 $(+33.4 \%, \mathrm{p}<0.001), \mathrm{CA} 3(+29.6 \%, \mathrm{p}<0.001)$, and GCL (+44.6\%, p<0.001) (Figs. 1 and 2, Table 1). The 5-HT6 IR levels then progressively decreased, returning to basal level by $72 \mathrm{~h}$ after acute ECS. These results demonstrate that similar pattern of increases in 5-HT6-IR was noted in all subfields of hippocampus and that the magnitude of increase in the GCL was greater than that in the CA1 and CA3 subfields of hippocampus.

One way ANOVA analysis shows that there was a significant differences in the CA1 (F4,19.4=35.2, $\mathrm{p}<0.001)$, CA3 (F4,19.6=16.2, $\mathrm{p}<0.001)$, and GCL $(\mathrm{F} 4,19.3=15.5, \mathrm{p}<0.001) .5$-HT6 IR levels were increased at $1 \mathrm{~h}$ in the CA1 $(+24.3 \%, \mathrm{p}<0.001)$, CA3 $(+16.7 \%$, $\mathrm{p}<0.05)$, and $\mathrm{GCL}(+21.9 \%, \mathrm{p}<0.05)$ of the hippocampus, reaching peak levels by 8 h post-ECS in CA1 $(+42.5 \%, \mathrm{p}<0.001)$, CA3 $(+40.4 \%, \mathrm{p}<0.001)$, and GCL (+38.1\%, p<0.001). 5-HT6 IR levels then progressively decreased, returning to basal level by $72 \mathrm{~h}$ after chronic ECS (Figs. 1 and 2, Table 1). These results demonstrate that the rate of increase of 5-HT6 IR after ECS tended to be more rapid. These results demonstrate a similar pattern of increases in 5-HT6-IR in all subfields of hippocampus, indicating that chronic ECS increases 5-HT6 IR in a manner similar to acute ECS. But, the rate of increase in 5-HT6 IR in all subfields of hippocampus tends to be more rapid after chronic ECS.

\section{DISCUSSION}

In the present study, 5-HT6 IR is evenly distributed in all subfields of the hippocampus in agreement with previous reports showing the distribution of 5-HT6 receptor mRNA [6] and immunoreactivity $[7,8]$ in the hippocampus. Acute ECS increased 5-HT6 IR in the CA1 subfield, reaching its peak at $8 \mathrm{~h}$ after the ECS, and returned to its basal level $72 \mathrm{~h}$ later. These timedependent changes in the CA1 subfield are similar to those in other subfields of the hippocampus. In addition, it is noteworthy that the degree of increase and time-dependent changes in 5-HT6 IR in chronic ECS were not different from those observed after acute ECS. This result is interesting in that acute and chronic administrations of 5-HT6 receptor agonist did not yield any difference in extracellular GABA levels in the frontal cortex in a microdialysis study [25], indicating a lack of neurochemical tolerance after repeated 5-HT6 receptor stimulation in the frontal cortex. These results suggest that 5-HT6 receptor in the hippocampus may be dynamically regulated by ECS and that this 
Acute ECS

CON

$\Delta$

\section{$1 \mathrm{~h}$}

$\Delta$
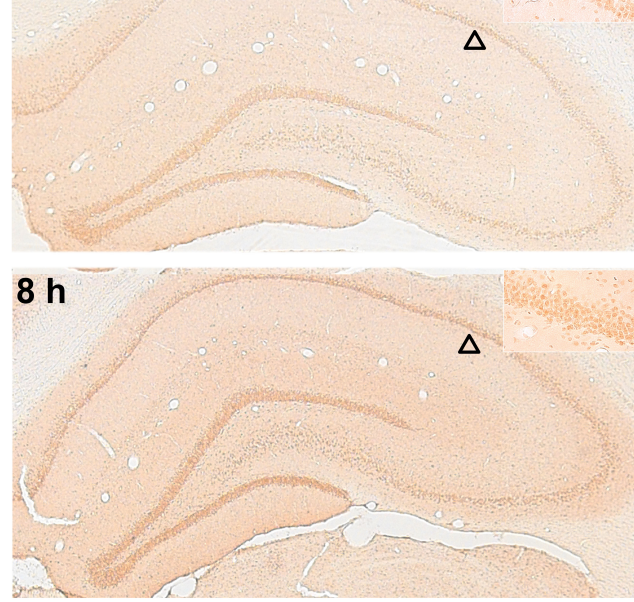

$24 \mathrm{~h}$

$\Delta$

$72 \mathrm{~h}$

$\Delta$

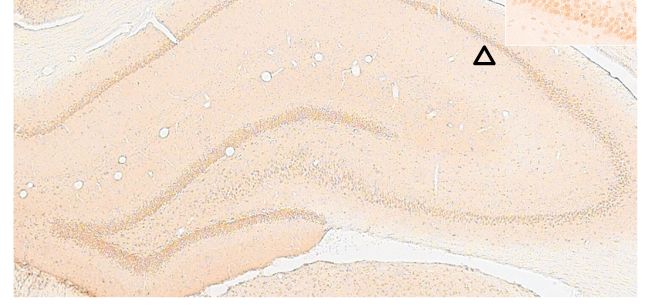

\section{Chronic ECS}

CON

$\Delta$

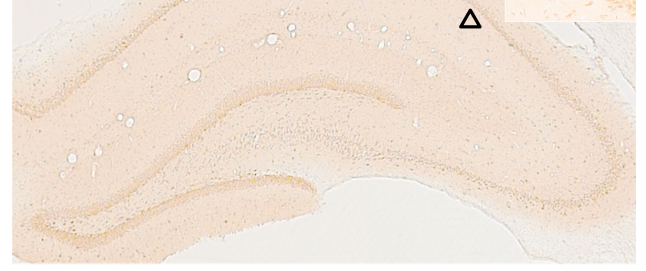

$1 \mathrm{~h}$
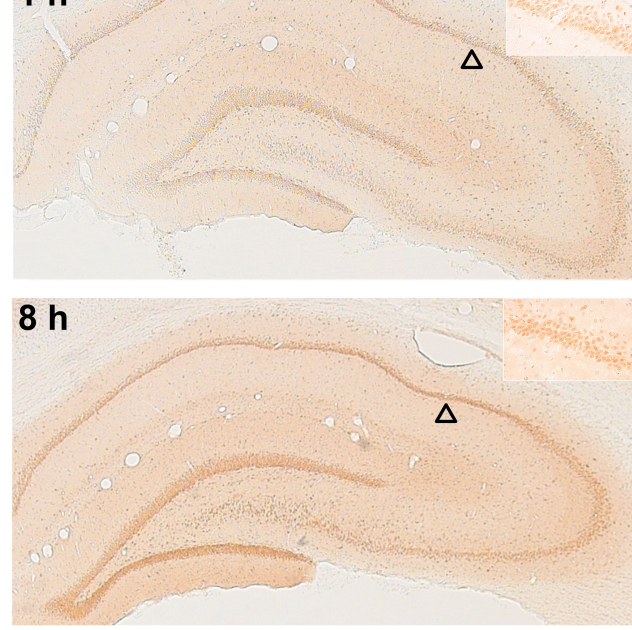

$24 \mathrm{~h}$

$\Delta$

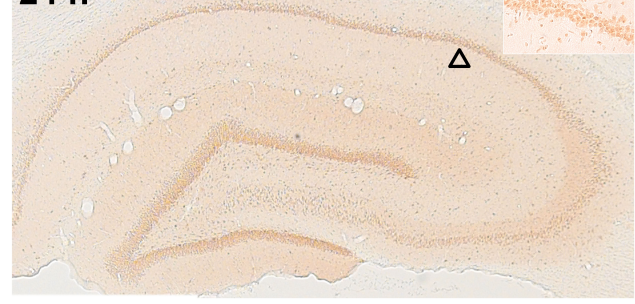

$72 \mathrm{~h}$

$\Delta$

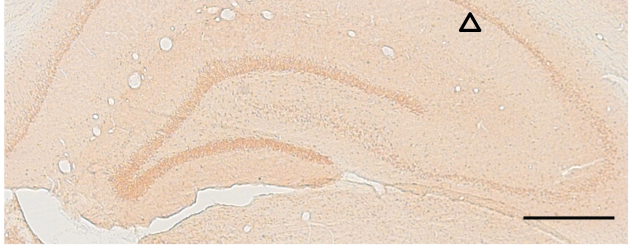

Fig. 2. Representative photographs of 5-HT6 IR in the areas CA 1, CA 3 , and GCL in the hippocampus after acute and chronic ECS. Higher magnifications of the pyramidal layer of CA1 are represented at upper right corners. Arrows indicate the area of magnification. Scale bar, $500 \mu \mathrm{m}$. Abbreviations as in Fig. 1.

Table 1. Effect of acute and chronic ECS on 5-HT6 IR levels in the CA1 and CA3 of the hippocampus

\begin{tabular}{|c|c|c|c|c|c|c|c|c|c|c|}
\hline & \multicolumn{5}{|c|}{ Acute } & \multicolumn{5}{|c|}{ Chronic } \\
\hline & CON & $1 \mathrm{~h}$ & $8 \mathrm{~h}$ & $24 \mathrm{~h}$ & $72 \mathrm{~h}$ & CON & $1 \mathrm{~h}$ & $8 \mathrm{~h}$ & $24 \mathrm{~h}$ & $72 \mathrm{~h}$ \\
\hline CA1 & $46.2 \pm 1.3$ & $50.9 \pm 0.6^{b}$ & $62.6 \pm 0.8^{c}$ & $50.9 \pm 0.7^{\mathrm{b}}$ & $44.6 \pm 0.9$ & $42.7 \pm 0.8$ & $53.0 \pm 0.7^{\mathrm{c}}$ & $60.8 \pm 1.7^{\mathrm{c}}$ & $51.2 \pm 0.5^{\mathrm{b}}$ & $48.1 \pm 1.1$ \\
\hline CA3 & $52.6 \pm 3.0$ & $57.2 \pm 2.3$ & $67.3 \pm 1.8^{\mathrm{b}}$ & $55.4 \pm 1.0$ & $48.8 \pm 1.9$ & $52.3 \pm 1.6$ & $59.5 \pm 1.4^{\mathrm{a}}$ & $72.7 \pm 2.9^{c}$ & $61.9 \pm 0.9^{\mathrm{b}}$ & $52.6 \pm 1.3$ \\
\hline
\end{tabular}

The results are expressed as the optical density and represent means \pm standard error of the mean (SEM) of data from 9 rats in each group. ${ }^{a} \mathrm{p}<0.05$; ${ }^{\mathrm{b}} \mathrm{p}<0.01 ;{ }^{\mathrm{c}} \mathrm{p}<0.001$ vs. $0 \mathrm{~h}$ (one-way ANOVA followed by post hoc Tukey's honestly significant difference test or post hoc Dunnett's T3 test). Abbreviations as in Fig. 1. 
regulation of 5-HT6 receptor in response to acute ECS appears not to be influenced by repeated ECS exposure.

ECS is known to induce amnesia, particularly with events that occur close to the time of ECS in humans [26,27], and this effect is also observed in rodents. For example, ECS induces retrograde [28] and anterograde amnesia [29] in studies using the Morris water maze test. Similarly, retrograde [30] and anterograde amnesia [31] after ECS have been observed in passive avoidance behavior. Considering that 5-HT6 receptor in the hippocampus is involved in learning and memory [32-34], it is probable that elevation of 5-HT6 receptor in the hippocampus may be involved in ECS-induced amnesia. At present, less is known about the effect of ECS on the impairment of learning and memory other than with respect to the Morris water maze test and passive avoidance behavior, but it should be pointed out that the amnesic effect of ECS appears to be cumulative in that repeated ECS induces more severe amnesia [30]. Moreover, retrograde amnesia often occurs when ECS is given shortly after the training of memory [29]. Inasmuch as the magnitude of 5-HT6 IR increase in chronic ECS did not differ from that in acute ECS in the present study, and 5-HT6 IR usually begins to rise $1 \mathrm{~h}$ later, reaching its peak $8 \mathrm{~h}$ after ECS, elevated 5-HT6 receptor in the hippocampus may play a limited role in ECS-induced amnesia.

There is also evidence that 5-HT6 receptor is involved in an antidepressant-like effect. For example, systemic administration of selective 5-HT6 receptor antagonists, such as SB-399885 and SB-271046, in rats displays an antidepressant-like effect, as revealed by reduced immobility duration in the FST [35]. One of the brain areas relevant for the antidepressant-like effect of 5-HT6 receptor antagonists appears to be the hippocampus, since intrahippocampal administration of SB-258585, a selective 5-HT6 receptor antagonist, reduces immobility duration [36]. However, with respect to the role of 5-HT6 receptor in this antidepressantlike effect, dissimilar results exist in that 5-HT6 receptor agonist also demonstrates an antidepressant-like effect in the mouse TST [13] and in the rat FST [12]. Moreover, intrahippocampal administration of 5-HT6 receptor agonist, EMD386088, reduces immobility duration in the FST in rats, suggesting an antidepressant-like effect, and this effect is blocked by systemic administration of the selective 5-HT6 receptor antagonist SB-399885 [37]. Thus, it is interesting to note that both 5-HT6 receptor agonist and antagonist induce an antidepressant-like effect, but this effect has been suggested to be mediated via different mechanisms of action. Similar to the contradictory results for the involvement of 5-HT6 receptor agonist or antagonist in antidepressant-like effects, disparate findings regarding the antidepressant-like effects between acute and chronic ECS treatment have been presented.
Chronic ECS treatment produces an antidepressant-like effect in the FST because daily administration of ECS for 6 or 14 days in rats decreases the immobility duration in the FST [38]. The reduction in immobility duration is notable $6 \mathrm{~h}$ after the last session of 14-day ECS administration, and this effect persists up to 3 days after the last session [38]. In contrast, a single ECS treatment in mice has no effect alone on the antidepressant-like effect in FST [39], and a similar effect is observed in rats [40]. Considering these results, together with the role of 5-HT6 receptor agonist or antagonist in the antidepressant-like effect, it is unlikely that elevated 5-HT6 receptor in the hippocampus plays a role in the antidepressant-like effect of ECS.

At present, it is not clear how ECS increases 5-HT6 IR in the hippocampus. One possible mechanism involves glucocorticoids because decreased plasma corticosterone levels by adrenalectomy increases 5-HT6 mRNA in the CAl of the hippocampus, which is partly restored by corticosterone replacement [6]. However, previous study demonstrated that a single ECS and repeated ECS for 10 days significantly increase plasma corticosterone, although the magnitude of increase appears to be attenuated with repeated exposure [41]. In addition, elevated 5-HT6 mRNA is only observed in the CAl after adrenalectomy, but the increase in the 5-HT6 IR was observed in all subfields of hippocampus after ECS. Moreover, considering that elevated plasma corticosterone levels have no effect on 5-HT6 mRNA levels in the subfields of hippocampus [6], the ECS-induced increase in 5-HT6 IR in the hippocampus is unlikely to be mediated by changes in plasma corticosterone. Alternatively, it is possible that diminished serotonin release induces a compensatory increase in 5-HT6 IR in the hippocampus, as suggested previously [41]. However, there is evidence that acute ECS increases serotonin release [42], although chronic ECS for 10 days does not alter serotonin release $[43,44]$ or rather increases serotonin levels in the hippocampus [45]. Thus, changes in serotonin release in the hippocampus may not be related to ECS-induced increase in 5-HT6 IR in the hippocampus. Further studies will be needed to identify underlying mechanism for the elevation of 5-HT6 receptor in the hippocampus induced by ECS.

In summary, our results demonstrate that acute and chronic ECS increases 5-HT6 IR in all subfields of the hippocampus in a time-dependent manner and that chronic ECS is found not to alter the magnitude of increase and time-dependent changes in 5-HT6 increase observed after acute ECS. These results suggest that both acute and chronic ECS dynamically regulate 5-HT6 IR in rat hippocampus, and indicates that the magnitude and timedependent changes in 5-HT6 IR in the hippocampus may not be influenced by repeated ECS treatment. 


\section{ACKNOWLEDGMENTS}

This study was supported by grants from the National Research Foundation of Korea (NRF-2010-0024048).

\section{REFERENCES}

1. Ploski JE, Newton SS, Duman RS (2006) Electroconvulsive seizure-induced gene expression profile of the hippocampus dentate gyrus granule cell layer. J Neurochem 99:1122-1132.

2. Haddjeri N, Blier P, de Montigny C (1998) Long-term antidepressant treatments result in a tonic activation of forebrain 5-HT1A receptors. J Neurosci 18:10150-10156.

3. Marek GJ (2008) Regulation of rat cortical 5-hydroxytryptamine $2 \mathrm{~A}$ receptor-mediated electrophysiological responses by repeated daily treatment with electroconvulsive shock or imipramine. Eur Neuropsychopharmacol 18:498507.

4. Sackeim HA, Prudic J, Fuller R, Keilp J, Lavori PW, Olfson M (2007) The cognitive effects of electroconvulsive therapy in community settings. Neuropsychopharmacology 32:244-254.

5. Squire LR (1986) Memory functions as affected by electroconvulsive therapy. Ann N Y Acad Sci 462:307-314.

6. Yau JL, Noble J, Widdowson J, Seckl JR (1997) Impact of adrenalectomy on 5-HT6 and 5-HT7 receptor gene expression in the rat hippocampus. Brain Res Mol Brain Res 45:182-186.

7. Gérard C, Martres MP, Lefèvre K, Miquel MC, Vergé D, Lanfumey L, Doucet E, Hamon M, el Mestikawy S (1997) Immuno-localization of serotonin 5-HT6 receptor-like material in the rat central nervous system. Brain Res 746:207219.

8. Marazziti D, Baroni S, Pirone A, Giannaccini G, Betti L, Testa G, Schmid L, Palego L, Borsini F, Bordi F, Piano I, Gargini C, Castagna M, Catena-Dell'osso M, Lucacchini A (2013) Serotonin receptor of type 6 (5-HT6) in human prefrontal cortex and hippocampus post-mortem: an immunohistochemical and immunofluorescence study. Neurochem Int 62:182-188.

9. Masi G, Brovedani P (2011) The hippocampus, neurotrophic factors and depression: possible implications for the pharmacotherapy of depression. CNS Drugs 25:913-931.

10. Jun H, Mohammed Qasim Hussaini S, Rigby MJ, Jang MH (2012) Functional role of adult hippocampal neurogenesis as a therapeutic strategy for mental disorders. Neural Plast 2012:854285.

11. Gluck MA, Myers CE (1997) Psychobiological models of hippocampal function in learning and memory. Annu Rev Psychol 48:481-514.

12. Carr GV, Schechter LE, Lucki I (2011) Antidepressant and anxiolytic effects of selective 5-HT6 receptor agonists in rats. Psychopharmacology (Berl) 213:499-507.

13. Svenningsson P, Tzavara ET, Qi H, Carruthers R, Witkin JM, Nomikos GG, Greengard P (2007) Biochemical and behavioral evidence for antidepressant-like effects of 5-HT6 receptor stimulation. J Neurosci 27:4201-4209.

14. Foley AG, Murphy KJ, Hirst WD, Gallagher HC, Hagan JJ, Upton N, Walsh FS, Regan CM (2004) The 5-HT(6) receptor antagonist SB-271046 reverses scopolamine-disrupted consolidation of a passive avoidance task and ameliorates spatial task deficits in aged rats. Neuropsychopharmacology 29:93-100.

15. Hirst WD, Stean TO, Rogers DC, Sunter D, Pugh P, Moss SF, Bromidge SM, Riley G, Smith DR, Bartlett S, Heidbreder CA, Atkins AR, Lacroix LP, Dawson LA, Foley AG, Regan CM, Upton N (2006) SB-399885 is a potent, selective 5-HT6 receptor antagonist with cognitive enhancing properties in aged rat water maze and novel object recognition models. Eur J Pharmacol 553:109-119.

16. Marcos B, Cabero M, Solas M, Aisa B, Ramirez MJ (2010) Signalling pathways associated with 5-HT6 receptors: relevance for cognitive effects. Int J Neuropsychopharmacol 13:775-784.

17. Fink M (1979) Efficacy of ECT. Lancet 2:1303-1304.

18. Burnet PW, Sharp T, LeCorre SM, Harrison PJ (1999) Expression of 5-HT receptors and the 5-HT transporter in rat brain after electroconvulsive shock. Neurosci Lett 277:7982.

19. Altar CA, Whitehead RE, Chen R, Wörtwein G, Madsen TM (2003) Effects of electroconvulsive seizures and antidepressant drugs on brain-derived neurotrophic factor protein in rat brain. Biol Psychiatry 54:703-709.

20. Zetterström TS, Pei Q, Grahame-Smith DG (1998) Repeated electroconvulsive shock extends the duration of enhanced gene expression for BDNF in rat brain compared with a single administration. Brain Res Mol Brain Res 57:106-110.

21. Yun HM, Kim S, Kim HJ, Kostenis E, Kim JI, Seong JY, Baik JH, Rhim H (2007) The novel cellular mechanism of human 5-HT6 receptor through an interaction with Fyn. J Biol Chem 282:5496-5505.

22. Paxinos G, Watson C (2007) The rat brain in stereotaxic coordinates. 6th edition. Elsevier Academic Press, Boston.

23. Field A (2005) Discovering statistics using SPSS. 2nd edition. Sage Publications Ltd, London. 
24. Wilcox R (2011) Modern statistics for the social and behavioral sciences: a practical introduction. CRC Press, Boca Raton, FL.

25. Schechter LE, Lin Q, Smith DL, Zhang G, Shan Q, Platt B, Brandt MR, Dawson LA, Cole D, Bernotas R, Robichaud A, Rosenzweig-Lipson S, Beyer CE (2008) Neuropharmacological profile of novel and selective 5-HT6 receptor agonists: WAY-181187 and WAY-208466. Neuropsychopharmacology 33:1323-1335.

26. Donahue AB (2007) Electroconvulsive therapy and memory loss. JAMA 298:1862.

27. Lisanby SH (2007) Electroconvulsive therapy for depression. N Engl J Med 357:1939-1945.

28. Bohbot V, Otáhal P, Liu Z, Nadel L, Bures J (1996) Electroconvulsive shock and lidocaine reveal rapid consolidation of spatial working memory in the water maze. Proc Natl Acad Sci U S A 93:4016-4019.

29. Khan A, Lai H, Ukai Y, Mirolo MH (1994) NS-3, a TRH analog, reverses repeated ECS-induced deficits in water maze performance in the rat. Pharmacol Biochem Behav 47:477481.

30. Andrade C, Thyagarajan S, Vinod PS, Srikanth SN, Rao NS, Chandra JS (2002) Effect of stimulus intensity and number of treatments on ECS-related seizure duration and retrograde amnesia in rats. J ECT 18:197-202.

31. Lerer B, Stanley M, McIntyre I, Altman H (1984) Electroconvulsive shock and brain muscarinic receptors: relationship to anterograde amnesia. Life Sci 35:2659-2664.

32. Codony X, Vela JM, Ramírez MJ (2011) 5-HT(6) receptor and cognition. Curr Opin Pharmacol 11:94-100.

33. Mitchell ES, Neumaier JF (2005) 5-HT6 receptors: a novel target for cognitive enhancement. Pharmacol Ther 108:320333.

34. Woolley ML, Marsden CA, Fone KC (2004) 5-ht6 receptors. Curr Drug Targets CNS Neurol Disord 3:59-79.

35. Hirano K, Piers TM, Searle KL, Miller ND, Rutter AR, Chapman PF (2009) Procognitive 5-HT6 antagonists in the rat forced swimming test: potential therapeutic utility in mood disorders associated with Alzheimer's disease. Life Sci 84:558-562.
36. Wesołowska A (2008) The anxiolytic-like effect of the selective 5-HT6 receptor antagonist SB-399885: the impact of benzodiazepine receptors. Eur J Pharmacol 580:355-360.

37. Nikiforuk A, Kos T, Wesołowska A (2011) The 5-HT6 receptor agonist EMD 386088 produces antidepressant and anxiolytic effects in rats after intrahippocampal administration. Psychopharmacology (Berl) 217:411-418.

38. Li B, Suemaru K, Cui R, Araki H (2007) Repeated electroconvulsive stimuli have long-lasting effects on hippocampal BDNF and decrease immobility time in the rat forced swim test. Life Sci 80:1539-1543.

39. Suzuki M, Masuda Y (1999) Effect of repeated electroconvulsive shock treatment on a depression model, mouse forced swimming. Tohoku J Exp Med 189:83-86.

40. Kawashima K, Araki H, Uchiyama Y, Aihara H (1987) Amygdaloid catecholaminergic mechanisms involved in suppressive effects of electroconvulsive shock on duration of immobility in rats forced to swim. Eur J Pharmacol 141:1-6.

41. Thiagarajan AB, Gleiter CH, Mefford IN, Eskay RL, Nutt DJ (1989) Effect of single and repeated electroconvulsive shock on the hypothalamic-pituitary-adrenal axis and plasma catecholamines in rats. Psychopharmacology (Berl) 97:548552.

42. Zis AP, Nomikos GG, Brown EE, Damsma G, Fibiger HC (1992) Neurochemical effects of electrically and chemically induced seizures: an in vivo microdialysis study in the rat hippocampus. Neuropsychopharmacology 7:189-195.

43. Gur E, Lerer B, Newman ME (1997) Chronic electroconvulsive shock and 5-HT autoreceptor activity in rat brain: an in vivo microdialysis study. J Neural Transm 104:795-804.

44. Gur E, Dremencov E, Garcia F, Van de Kar LD, Lerer B, Newman ME (2002) Functional effects of chronic electroconvulsive shock on serotonergic 5-HT(1A) and 5-HT(1B) receptor activity in rat hippocampus and hypothalamus. Brain Res 952:52-60.

45. Jacobsen JP, Mørk A (2004) The effect of escitalopram, desipramine, electroconvulsive seizures and lithium on brainderived neurotrophic factor mRNA and protein expression in the rat brain and the correlation to 5-HT and 5-HIAA levels. Brain Res 1024:183-192. 